\title{
Enhancement of Nano-Biopolymer Antibacterial Activity by Pulsed Electric Fields
}

\author{
Mai. I. El-Kaliuoby ${ }^{1}$, Motaz Amer ${ }^{2}$ and Nader Shehata ${ }^{3,4,5,6, *}$ \\ 1 Faculty of Education, Alexandria University, Alexandria 21544, Egypt; mai.ismail@alexu.edu.eg \\ 2 Basic and Applied Science Institute, College of Engineering Arab Academy for Science, Technology and \\ Maritime Transports, Alexandria 21544, Egypt; motaz.amer@aast.edu \\ 3 The Bradley Department of Electrical and Computer Engineering, Virginia Tech, Blacksburg, VA 24061, USA \\ 4 Department of Engineering Mathematics and Physics, Faculty of Engineering, Alexandria University, \\ Alexandria 21544, Egypt \\ 5 Kuwait College of Science and Technology, Doha Area, 7th Ring Road, Safat 13133, Kuwait \\ 6 Utah Science Technology and Research (USTAR) Bio-Innovation Center, Utah State University, \\ Logan, UT 84341, USA \\ * Correspondence: nader.shehata@alexu.edu.eg
}

Citation: El-Kaliuoby, M.I.; Amer, M.; Shehata, N. Enhancement of Nano-Biopolymer Antibacterial Activity by Pulsed Electric Fields. Polymers 2021, 13, 1869. https:// doi.org/10.3390/polym13111869

Academic Editor: Yi-Chen Ethan Li

Received: 10 April 2021

Accepted: 30 May 2021

Published: 4 June 2021

Publisher's Note: MDPI stays neutral with regard to jurisdictional claims in published maps and institutional affiliations.

Copyright: (c) 2021 by the authors. Licensee MDPI, Basel, Switzerland. This article is an open access article distributed under the terms and conditions of the Creative Commons Attribution (CC BY) license (https:// creativecommons.org/licenses/by/ $4.0 /)$.

\begin{abstract}
Chronic wounds are commonly colonized with bacteria in a way that prevents full healing process and capacity for repair. Nano-chitosan, a biodegradable and nontoxic biopolymer, has shown bacteriostatic activity against a wide spectrum of bacteria. Effectively, pulsed electromagnetic fields are shown to have both wound healing enhancement and antibacterial activity. This work aimed to combine the use of nano-chitosan and exposure to a pulsed electric field to overcome two common types of infectious bacteria, namely P. aeruginosa and S. aureus. Here, bacteria growing rate, growth kinetics and cell cytotoxicity (levels of lactate dehydrogenase, protein leakage and nucleic acid leakage) were investigated. Our findings confirmed the maximum antibacterial synergistic combination of nano-chitosan and exposure against $P$. aeruginosa than using each one alone. It is presumed that the exposure has influenced bacteria membrane charge distribution in a manner that allowed more chitosan to anchor the surface and enter inside the cell. Significantly, cell cytotoxicity substantiates high enzymatic levels as a result of cell membrane disintegration. In conclusion, exposure to pulsed electromagnetic fields has a synergistic antibacterial effect against $S$. aureus and $P$. aeruginosa with maximum inhibitory effect for the last one. Extensive work should be done to evaluate the combination against different bacteria types to get general conclusive results. The ability of using pulsed electromagnetic fields as a wound healing accelerator and antibacterial cofactor has been proved, but in vivo experimental work in the future to verify the use of such a new combination against infectious wounds and to determine optimum treatment conditions is a must.
\end{abstract}

Keywords: natural biopolymers; nano-chitosan; pulsed electric fields; antibacterial; P. aeruginosa; S. aureus; wound healing

\section{Introduction}

Recently, the integration of an array of antimicrobial agents against resistant bacteria has opened great interest in overcoming the spread use of antibiotics. Nanoparticles have opened new areas for new antibacterial materials with novel properties and advanced characteristics [1-3]. Growing interest has arisen in chitosan biopolymer nanoparticles (ChNPs) as a biodegradable and nontoxic material with considerable bio-applications [4]. It has demonstrated a broad antibacterial activity against Gram-positive and Gram-negative bacteria [5] due to its unique biological characteristics. One of the most proper mechanisms of ChNPs' antibacterial action is based on the probability of electrostatic communication with either the bacterial cellular wall or the cell membrane. This electrostatic communication occurs between the positive charges of amino groups of glucosamine with the negative 
charge of the cell membranes of bacteria [6]. This interaction leads to variations in the surface of the cell, leading in turn to modifications in the membrane permeability which sequentially facilitate osmotic imbalance and efflux of intracellular substances that result in cell death [7].

To another extent, the consideration of ChNPs as bactericidal was limited recently to biostatic. Instead, the need for external cofactors to enhance its bactericidal impact has become a must [8-10]. Recently, the combination of using ChNPs and a laser diode as cofactors against $E$. coli strains was studied. The obtained results indicated the ability of the laser diode to excite the ChNPs and hence cause photothermal lysis of E. coli cells. The synergism between using ChNPs and a laser diode increases the bacteria inhibition process and causes a more lethal impact than using ChNPs alone [11]. In another way, the antibacterial effect of nano-silver particles against E. coli was studied in combination with ultraviolet light by Zazouli et al. [12]. The obtained results confirmed the intensified disinfection ability of nanoparticles combined with exposure to ultraviolet light which was attributed to the production of electrons, active holes and active radicals by the irradiation. The great interest during the last ten years and the series of questions raised about the negative and/or positive biological effects of electromagnetic waves, especially in the extremely low frequency (ELF) range, make this an open-ended research area. In this regard, the influence of ELF pulsed electric fields (PEFs) on bacteria as co-stressors showed remarkable effects on treatment bio-availability and increased the antibacterial susceptibility as reported elsewhere [13-20]. A nontraditional antibacterial treatment was performed by using an array of nanofiber mats together with exposure to electromagnetic waves. The applied electromagnetic waves (EMWs) were shown to be a synergistic cofactor in killing bacteria even at low nanofiber mat concentrations [21]. In a different way, exposure to a magnetic field of $1.8 \mathrm{mT}$ for $20 \mathrm{~min}$ was adopted to develop the kinetics of dentin/enamel re-mineralization in combination with nano-chitosan gels. The results established the applicability of using a magnetic field as an accelerator for tooth remineralization [22]. In addition to the ability of PEF to decrease the bacteria growth rates it also accelerates the wound healing process $[23,24]$. PEF efficiently improves of wound healing kinetics by redistributing and activating important membrane receptors, manipulation of ion transportation at the wound and the ability to direct cell migration.

One of the most serious problems in wound treatment is healing of chronic wounds that fail to heal through the body's natural healing processes. Most causes of delayed healing in chronic wounds are, but not limited to, microbial infection, poor blood circulation and other severe impaired healing processes such as lack of epithelial migration, angiogenesis, and cell proliferation. Wound infection occurs due to a disturbed host-bacteria equilibrium process in a traumatized tissue environment which favors bacteria and leads to inhibition of the healing process [25]. In addition, it is important to bear in mind that the microbial contamination may not be only on the surface but also deep in the wound tissue, that could be complicated by the presence of biofilms and/or antibiotic resistance. As a result, external exposure to PEF as a cofactor with antibacterial agents to enhance the wound healing process and accelerate tissue repair are required.

To address the current challenges, we proposed the combine used of ChNPs and ELF-PEFs as an antimicrobial and wound healing accelerator. To demonstrate such a new combination, the antibacterial effects of ChNPs and ELF-PEFs were tested against Gram positive and negative bacteria models as an example of highly infectious wounds. In chronic wounds, Staphylococcus aureus (S. aureus) and Pseudomonas aeruginosa (P. aeruginosa) colonize about $93.5 \%$ and $52.2 \%$ of patients with chronic leg ulcers, respectively [26-29]. The bacterium $P$. aeruginosa has the ability to establish itself in biofilms [30,31]. These biofilms are complex structures that act as efficient barriers against antibiotics and thus the host immune system weakens the bacterial infections and wounds become more difficult to heal [32]. On the other hand, S. aureus is an antibiotic-resistant pathogenic bacterium, which enhances infections by producing factors that cause bacteremia, endocarditis, skin tissue infections, and also hospital-acquired infections [33,34]. Therefore, the antibacterial effects 
of ChNPs alone, ELF-PEFs alone and combinations of them were tested against P. aeruginosa and $S$. aureus. The antibacterial effects were determined by studying the bacterial growing curves, growth kinetics and cytotoxicity. Evaluation of bacteria cytotoxicity was obtained by monitoring levels of lactate dehydrogenase (LDH), protein leakage and nucleic acid leakage for both strains.

\section{Materials and Methods}

\subsection{Electric Field Exposure System}

The exposure was achieved by using two parallel plate capacitor systems connected to a DC power supply locally manufactured at the Physics Lab of the Alexandria University Faculty of Science (Alexandira, Egypt). The input DC voltage of $6 \mathrm{~V}$ was directed to the exposure system through an electronic switching device of $50 \%$ duty cycle to maintain interrupted currents at different frequencies. The interrupted currents are then directed into a DC/DC voltage converter to amplify the voltage up to $400 \mathrm{~V}$. For exposure purposes, the output voltages were conducted through rectangular aluminium plates of $20 \times 10 \mathrm{~cm}^{2}$ and separated by $10 \mathrm{~cm}$. The supernatant samples were placed at the midline between the two plates and electric field was adapted between the two plates and confirmed by using a field meter type Tri-field ${ }^{\circledR}$ TF2 EMF meter (AlphaLab, Salt Lake City, UT, USA) of accuracy of $\pm 5 \%$. The measured peak electric field intensity was found to be $3.70 \pm 0.18 \mathrm{kV} / \mathrm{m}$ as recorded at the exposure point located in the central axis of the supernatant glass tubes. The pulse shape was displayed using a GOS-620 type oscilloscope (GW Instek, New Taipei City, Taiwan) and found to be squared pulses. The exposure time was adjusted to be $30 \mathrm{~min}$ for all experimental conditions. For controlling the exposure conditions, the supernatant glass tubes were placed on top of a nonconductive stand and the temperature was adjusted to be in the $27^{\circ} \mathrm{C}$ range as recorded by using an electronic thermometer type SP Bel-Art, H-B DURAC Calibrated Electronic Thermometer (Durac, Beijing, China). It is worth clarifying that there is no conflict between our exposure facility and the safe limits that have been addressed by the International Commission on Non-Ionizing Radiation Protection.

\subsection{Nano-Chitosan Characterizations}

The chitosan nanoparticles (ChNPs) used in the present work were purchased from Alpha Chemika Co. (Mumbai, India). Their shape and size were confirmed by scanning electron microscopy (SEM) as shown in Figure 1. The samples were sputter-coated with gold and the morphology observed at an acceleration voltage of $20 \mathrm{kV}$ with a highest magnification of $40,000 \times \mathrm{g}$. Figure 1a showed grains of ChNPs without agglomeration and the size distribution profile indicated a particle size range between $28.61 \mathrm{~nm}$ to $57.84 \mathrm{~nm}$ and an average size of about $39.68 \pm 0.22 \mathrm{~nm}$, as presented in Figure $1 \mathrm{~b}$.

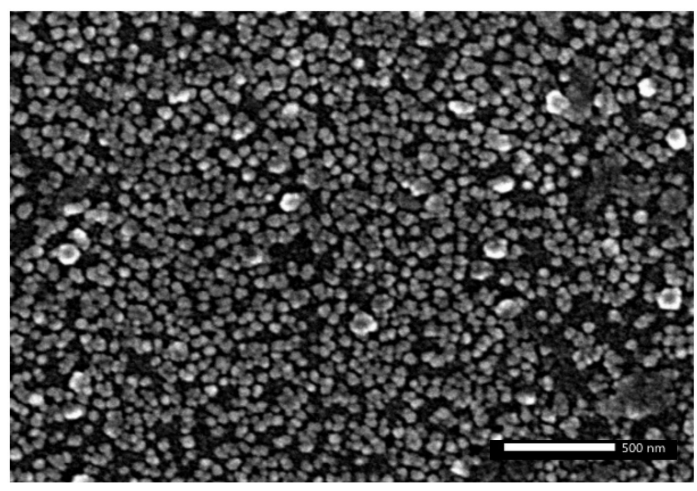

(a)

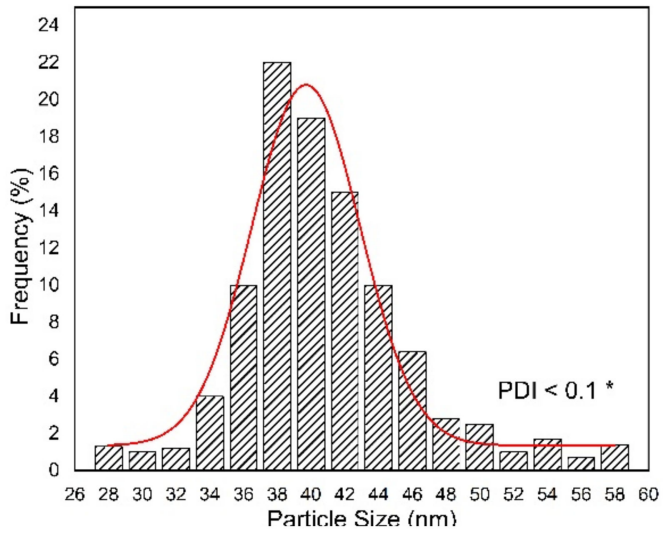

(b)

Figure 1. (a) SEM image of ChNPs indicates grains of particles without agglomeration, and (b) histogram of particle sizes distribution shows average size of ChNPs to be $39.68 \mathrm{~nm}$. * Polydispersity Index (PDI). 


\subsection{Bacterial Strains and Replications}

In this work, we used two bacterial strains. One is P. aeruginosa-ATCC 27,853 as a Gram negative model bacterium and the other one is S. aureus-ATCC 25,923 as a Gram positive model organism. It should be stated that the Gram positive bacterial strain of S. aureus was a methicillin-susceptible MSSA. The bacterial strains of P. aeruginosa and S. aureus were plated on nutrient agar plates for further antibacterial tests. The growing conditions were kept constant for both strains during the whole experiment in which approximately $10^{5}$ colony forming units (CFU) from each pathogen were inoculated on agar plates and allowed for incubation $24 \mathrm{~h}$ at $37^{\circ} \mathrm{C}$. Subcultures from each bacterial strain were obtained by periodic inoculation of several colonies to maintain fresh strains.

\subsection{Bacterial Growth Characteristics and Antibacterial Impacts}

The bacteriostatic impact of ChNPs against bacterial strains was determined by using a plate count technique in which both positive and negative strains $(0.5 \mathrm{McF}$ arland $\equiv$ $1.5 \times 10^{8} \mathrm{CFU} / \mathrm{mL}$ ) were inoculated in broth media and exposed to serial concentrations of ChNPs. In advance, ChNPs stock solution was prepared by adding chitosan ChNPs in acetic acid solution $(1 \% w / v)$ and stirring for $12 \mathrm{~h}$ to dissolve the powder. The final concentration of the ChNPs stock was $1 \%(w / v)$ and it was diluted as needed using deionized distilled water. Serial dilutions starting from $500 \mathrm{mg} / \mathrm{mL}$ were reduced by a factor of 1.5 to a concentration of $1.14 \mathrm{mg} / \mathrm{mL}$. It is worth clarifying that ChNPs powder was sterilized by exposure to ultraviolet radiation and broth media were sterilized by autoclaving at a temperature up to $121^{\circ} \mathrm{C}$. Furthermore, inoculations of $100 \mu \mathrm{L}$ from each bacterial strain were mixed with $100 \mu \mathrm{L}$ of ChNPs for all serial dilutions and left to incubate $24 \mathrm{~h}$ at $37^{\circ} \mathrm{C}$. The concentration at which no visible growth of bacteria in broth media was considered as minimum inhibitory concentration (MIC) and the concentration at which three or less colonies were observed ( $>99.9 \%$ killed) after inoculation in agar plates was considered as minimum bactericidal concentration (MBC) [35]. To further select concentrations less than the MIC levels of ChNPs were supplemented to both bacterial strains (positive control samples $)$ in broth media and exposed to PEF $((3.70 \pm 0.18) \mathrm{kV} / \mathrm{m}-30 \mathrm{~min})$ at $0.7 \mathrm{~Hz}$ and $20 \mathrm{~Hz}$ for P. aeruginosa and S. aureus respectively, as reported by Fadel et al. [36] and ElKaliuoby et al. [37]. The viability of bacterial cells is calculated as a percentage relative to samples that didn't receive any treatment (negative control ones): viability $\%=[$ (average count of control - average count of treated)/average count of control] $\times 100$. In this regard, the growth characteristics were studied by observing cell populations as monitored by turbidity measured in terms of optical density at $600 \mathrm{~nm}\left(\mathrm{OD}_{600}\right)$. [37] The growing characteristics were presented as growth curves plotted between $\mathrm{OD}_{600}$ and incubation time to represent the effect of exposure in bacterial growth phases. Furthermore, the growth dynamics were obtained by analyzing the growing curves and calculating their arbitrary rate constants as follows:

$$
\text { Arbitrary growth rate constant }=1 / \mathrm{t} \ln \left(\mathrm{N} / \mathrm{N}_{0}\right)
$$

where $\mathrm{N}$ is the bacterial cell count at time (t) and $\mathrm{N}_{0}$ the initial cell count. In proceeding, the arbitrary rate constants were trended and plotted versus ChNPs concentrations (0-100 mg/mL) [38].

\subsection{Bacterial Cytotoxicity Tests}

Moreover, the cytotoxicity due to supplement of ChNPs and exposure to PEF for each bacterial strain was evaluated by measuring levels of LDH, protein leakage and nucleic acid leakage in the broth media. The LDH levels were obtained by monitoring changes in supernatant turbidity. The protein leakage levels were measured by the Bradford method [39,40] using Coomassie protein assay reagent (Pierce, Rockford, IL, USA) as adapted by $\mathrm{Li}$ et al. [41]. The nucleic acid leakage was evaluated by measuring the amount of acid released in the media as adopted by Reddy et al. [42]. The cytotoxicity 
parameters of $\mathrm{LDH}$, protein leakage, and nucleic acid leakage were evaluated relative to the negative control samples by using a microplate spectrophotometer system (Spectramax190, Molecular Devices, San Jose, CA, United States) at $490 \mathrm{~nm}, 595 \mathrm{~nm}$ and $260 \mathrm{~nm}$, respectively. The data is represented in relative percentages as follows:

$$
\text { Parameter } \%=[(\text { treated samples }- \text { control samples }) / \text { control samples }] \times 100 .
$$

\subsection{Statistical Analysis}

We designed the experiments based on three replicates. Each replicate has 10 samples per each treatment condition (i.e., the total number of samples is 30 per treatment). Then we averaged the results of these 10 samples to get one result/replicate and used these three results/treatment to perform statistical analysis. The statistical analysis was executed by using the SPSS package version 21 (IBM, Armonk, NY, USA) for Windows and all data was presented in terms of mean values \pm standard deviation (SD). Furtherly, the data were statistically evaluated by one-way analysis of variance (ANOVA) to determine the significance of differences between results. The differences were considered by the post hoc Tukey test to be statistically significant at $p<0.05$ and statistically highly significant at $p<0.01$.

\section{Results and Discussion}

The bacteriostatic and bactericidal effects of ChNPs were monitored against both bacteria models as tabulated in Table 1, whereas MIC and MBC levels were obtained as shown in Figure 2.

Table 1. List of $P$. aeruginosa and $S$. aureus counts (CFU/mL $\pm \mathrm{SE})$ under supplement of ChNPs at different concentrations.

\begin{tabular}{ccc}
\hline $\begin{array}{c}\text { Conc. of ChNPs } \\
(\mathbf{m g} / \mathbf{m L})\end{array}$ & $\begin{array}{c}\text { Count of } \text { P. aeruginosa } \\
(\mathbf{C F U} / \mathbf{m L})\end{array}$ & $\begin{array}{c}\text { Count of S. aureus } \\
\text { (CFU/mL) }\end{array}$ \\
\hline 65.8 & NG & NG \\
43.9 & NG & NG \\
29.3 & NG & $(7.77 \pm 0.62) \times 10^{1}$ \\
19.5 & NG & $(4.79 \pm 0.51) \times 10^{7}$ \\
13.1 & $(3.09 \pm 0.13) \times 10^{1}$ & $(2.91 \pm 0.33) \times 10^{8}$ \\
10.6 & $(7.76 \pm 0.18) \times 10^{3}$ & $(8.51 \pm 0.11) \times 10^{8}$ \\
5.78 & $(1.62 \pm 0.26) \times 10^{6}$ & $(1.28 \pm 0.12) \times 10^{9}$ \\
3.19 & $(4.07 \pm 0.43) \times 10^{7}$ & $(2.81 \pm 0.31) \times 10^{9}$ \\
1.71 & $(8.71 \pm 0.35) \times 10^{8}$ & $(5.37 \pm 0.22) \times 10^{9}$ \\
\hline
\end{tabular}

CFU: colony forming units, NG: No Growth.

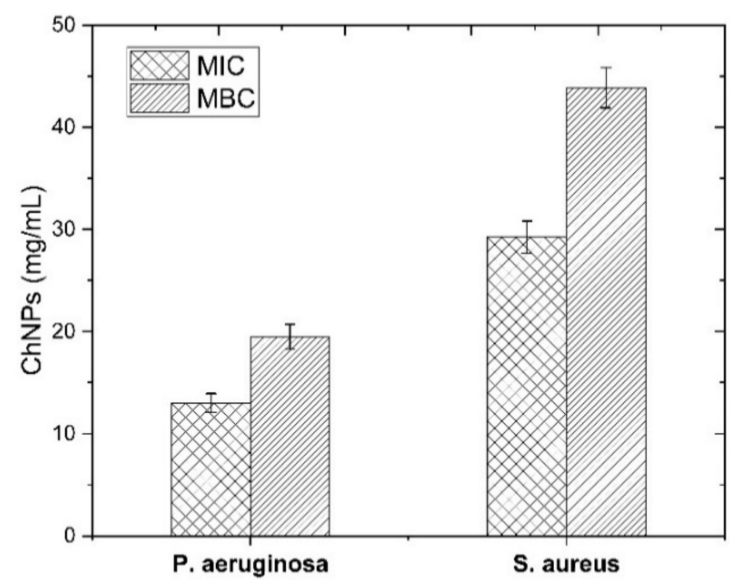

Figure 2. MIC and MBC levels of bacteria strains after supplementing with ChNPs at different concentrations. 
The bacteriostatic levels indicated a higher concentration $(29.3 \mathrm{mg} / \mathrm{mL})$ for $S$. aureus than for $P$. aeruginosa $(13.1 \mathrm{mg} / \mathrm{mL})$, which reflects the greater potential activity of ChNPs against Gram negative bacteria than positive ones. In the same way, levels of ChNPs that caused $>99.9 \%$ of bacteria to be killed indicated a supplementation of $19.5 \mathrm{mg} / \mathrm{mL}$ and $43.9 \mathrm{mg} / \mathrm{mL}$ of ChNPs against $P$. aeruginosa and $S$. aureus, respectively. There are multiple possible interactions between ChNPs and bacteria. The antibacterial activity of ChNPs resulted from its polycationic structure due to the protonation of $-\mathrm{NH}_{2}$ groups on the C-2 position of the D-glucosamine repeat unit as reported elsewhere $[43,44]$, so the interaction between positively charged ChNPs with negatively charged bacteria cell surface deactivates the normal functions of the membrane. The deactivation happens either by enhancing the leakage of intracellular components or by damping the transport of nutrients into cells [45]. The dysfunction of the bacterial cell membrane leads to changes in cell permeability that allow the ChNPs to enter inside the cell and so, it may bind to DNA and disrupt its replication, which in turns leads to bacterial cell death [46]. Comparing Gram negative and positive bacteria, ChNPs show variable interaction mechanisms based on the differences in the cell wall and cell membrane morphological structure of both types. Our findings resemble results reported elsewhere [47-51] and confirm the higher effect of ChNPs against Gram negative bacteria than positive ones. The cell membrane structure of Gram negative bacteria contains lipopolysaccharide anionic groups (phosphate and pyrophosphate groups) that supply more negative charges to the cellular outer surface. Such an excess of static negative charges at the cell surface allows ChNPs to interact more strongly with Gram negative stained bacteria than positive ones [52-54].

The aim of the current study was to enhance the impact of ChNPs as an antibacterial agent and therefore this work was extended to evaluate their combination with exposure to PEF. It is known that the influence of external PEF is dependent on the physical field conditions such as field strength, applied frequency and exposure time, so it is worth stating that the exposure to our specific field conditions $(50 \%$ duty cycle, $3.70 \pm 0.18, \mathrm{kV} / \mathrm{m}$, $30 \mathrm{~min}$ at $0.7 \mathrm{~Hz}$ and $20 \mathrm{~Hz}$ ) has non-ionizing and non-thermal effect and has a very low encounter energy. Therefore, it is proposed not to cause any specific molecular changes in the ChNPs structure and/or any cellular ionic constituents [55-57].

The supplement of ChNPs was adapted at levels of $3 \mathrm{mg} / \mathrm{mL}$ and $10 \mathrm{mg} / \mathrm{mL}$, lower than the MIC levels for P. aeruginosa and S. aureus, respectively. The cell viability percentages of supernatants treated with ChNPs, PEF, and combinations of them were calculated in comparison to control ones as depicted in both Figures 3 and 4.

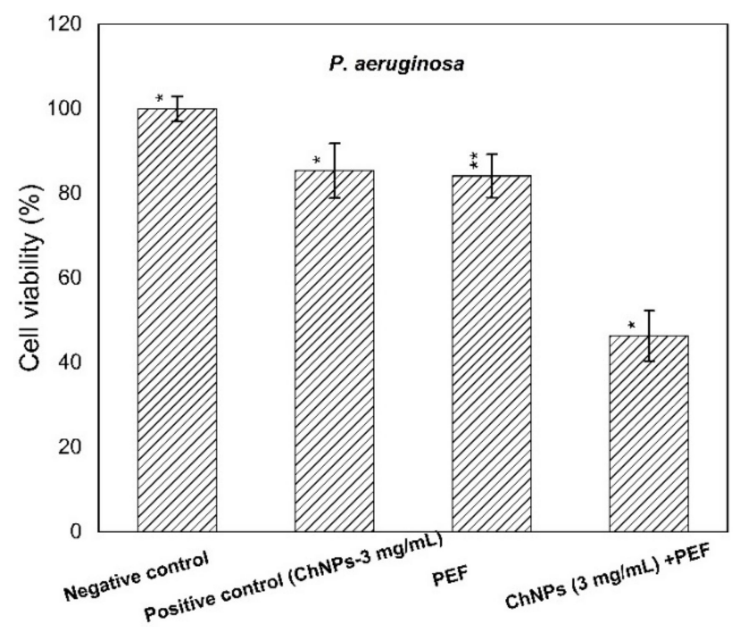

Figure 3. Cell viability percentages of $P$. aeruginosa relative to control bacterial counts. ${ }^{*}$ statistically significant, ${ }^{* *}$ statistically highly significant. 


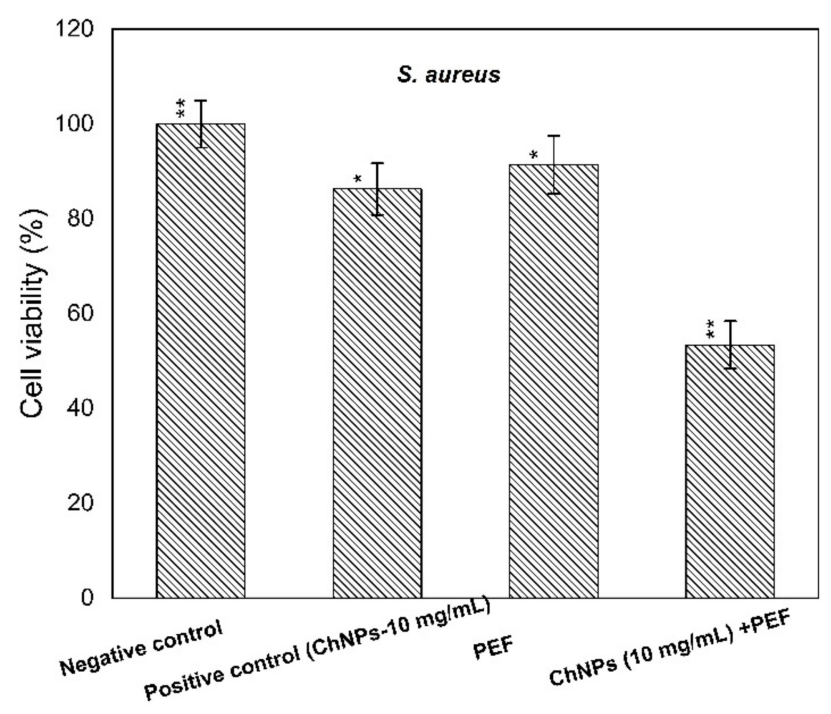

Figure 4. Cell viability percentages of $S$. aureus relative to control bacterial counts. ${ }^{*}$ statistically significant, ${ }^{* *}$ statistically highly significant.

The obtained results indicated a remarkable antibacterial enhancement of the ChNP activity when combined with PEF compared to using ChNPs alone, by $40 \%$ and $30 \%$ for $P$. aeruginosa and S. aureus, respectively. One can explain the direct interaction of exposure to PEF based on the physics of the field-charge system. Of note the electric fields have the ability to drive, accelerate and orient charges under the field gradient, so electric field application may cause charges at the outer cell membrane to be dislocated. The combination of PEF exposure represents an extra cofactor to enhance ChNP activity not only at the cell surface but also to be driven more inside the cell and attach to DNA.

Growth-time dependent changes were observed by recording the OD $(600 \mathrm{~nm})$ every hour for samples treated by ChNPs alone and combined with exposure to PEF as shown in Figures 5 and 6 for P. aeruginosa and S. aureus, respectively. The recorded data reflected the population density of bacterial cells within the growing broth media. It is known that as bacteria grow rapidly, the incident light through the broth scatters more and the OD values become higher. The growth curves shown in Figures 5 and 6 depict similar dispersions of curves for all tested samples that represent three growth phases (lag, log and stationary). Significantly, the growth of $P$. aeruginosa cells was affected by the supplement of ChNPs in a way it had delay in the cell reproduction in the growing phases and the curves tend to be shallower than control ones as shown in Figure 5. Exposure to PEF showed an unstructured effect that started with as a supportive cofactor that enhanced the growth of bacteria till the 10th $\mathrm{h}$ of incubation and was then followed with a disruptive reaction that inhibited bacterial growth. The combination of exposure to PEF and supplementation with ChNPs provided the most powerful weapon against bacteria that caused the highest delay of bacterial replication and least bacteria population in the stationary phase. In addition, S. aureus growth curves presented in Figure 6 show almost the same growing population till the 8th $\mathrm{h}$ of incubation as compared to the control except for the samples treated with a combination of ChNPs and PEF. Like the Gram negative bacteria, a remarkable disruptive influence of ChNPs and PEF against $S$. aureus growth was observed even in the lag phase. Such an effect confirms the abnormalities in cellular metabolic activity accompanied by alterations in the bacteria cell division process. In particular, the combination of PEF and ChNPs shows a remarkable progression in its cell uptake and so drives more charged ChNPs inside the cell to hinder the DNA formation and stop the ability to replicate [58]. 


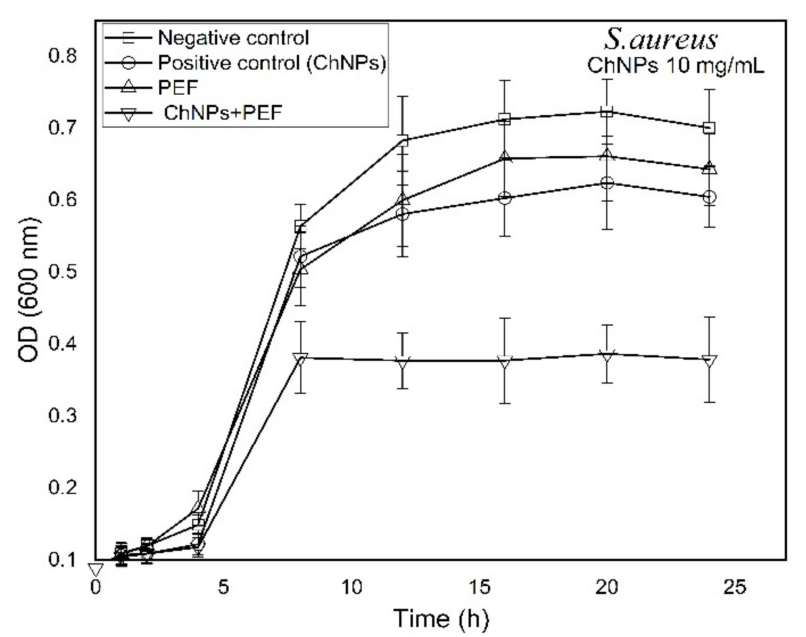

Figure 5. Growth time-dependent characteristic curves of P. aeruginosa as treated by ChNPs $(3 \mathrm{mg} / \mathrm{mL}$ ) and PEF each alone and combined with exposure to PEF.

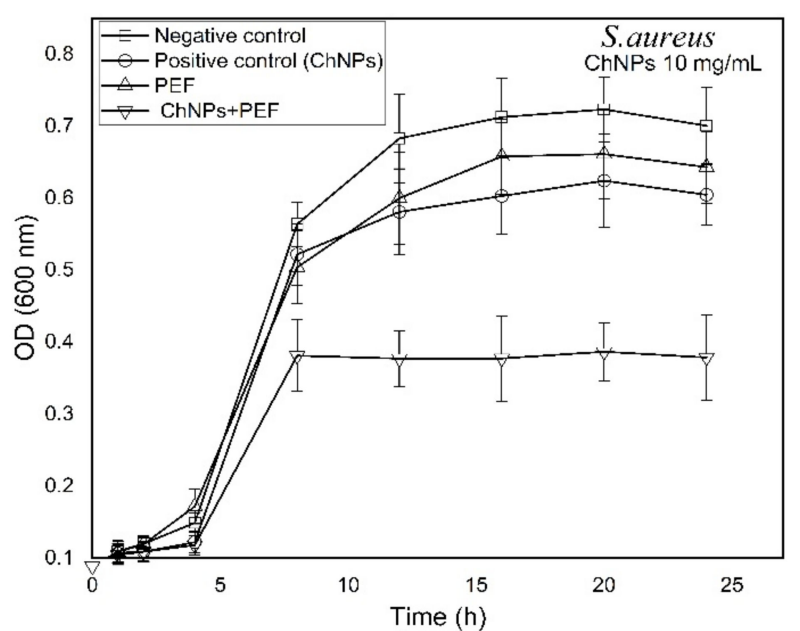

Figure 6. Growth time-dependent characteristic curves of $S$. aureus as treated by ChNPs $(10 \mathrm{mg} / \mathrm{mL})$ and PEF each alone and combined with exposure to PEF.

Growth curves of each bacterial strain were analyzed and the growth rates were calculated for samples treated by ChNPs alone and combined with PEF. Then, arbitrary growth rate constants were graphed versus concentrations of ChNPs. Both Figures 7 and 8 show the trend lines of the rate constants for P. aeruginosa and S. aureus, respectively. The trend lines of both bacterial samples treated by ChNPs combined with PEF showed significantly more diversity than with ChNPs alone. The trend lines of combined samples showed that the ChNP concentration dependency behevaed in a manner where as the concentration increases, the lines become more tilted. The slopes of arbitrary growth rate constants were calculated and are tabulated in Table 2. The influence of exposure to PEF showed the synergistic antibacterial impact of ChNPs as its combination displayed negative slope value increases by $90 \%$ and $60 \%$ for $P$. aeruginosa and S. aureus, respectively. 


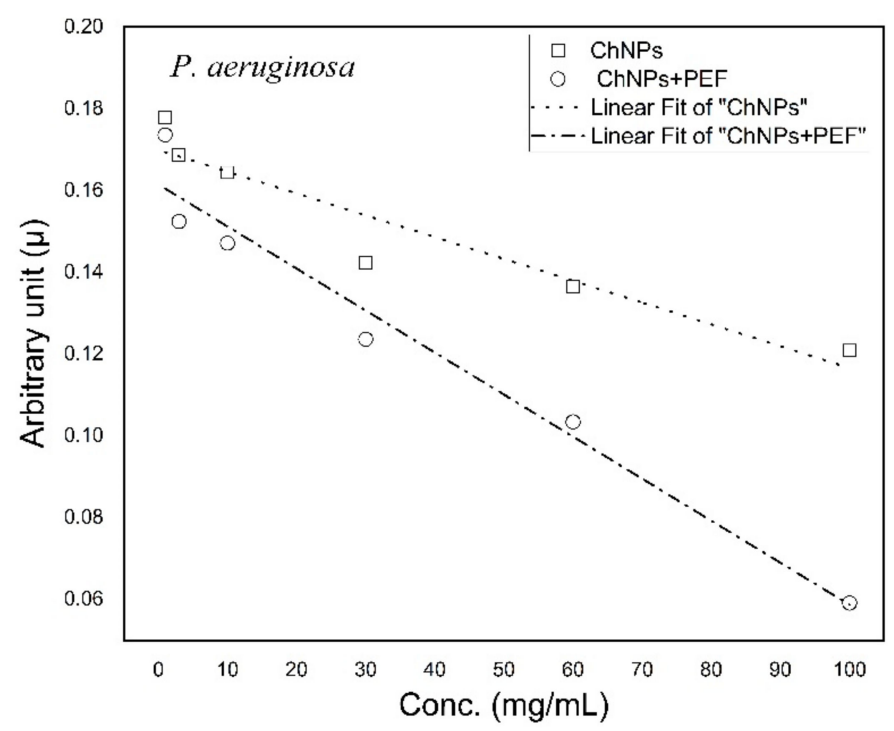

Figure 7. Trend lines of arbitrary constant values for P. aeruginosa treated by ChNPs alone and combined with PEF.

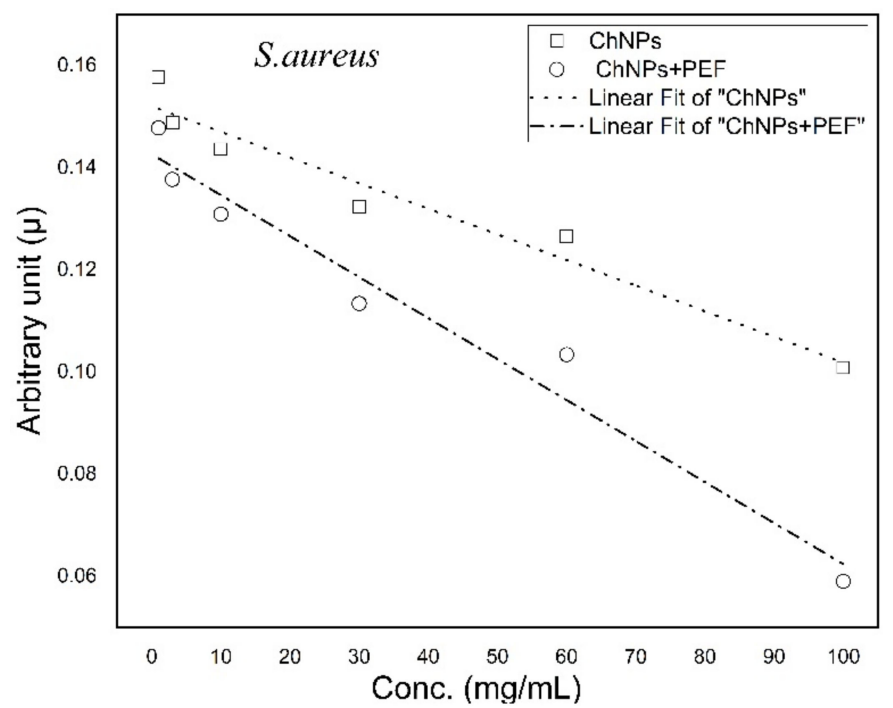

Figure 8. Trend lines of arbitrary constant values for S. aureus treated by ChNPs alone and combined with PEF.

Table 2. List of slope trend line values of arbitrary growth rate constants P. aeruginosa and S. aureus treated by ChNPs alone and combined with PEF.

\begin{tabular}{ccc}
\hline Treatment Condition & $\begin{array}{c}\text { Slope of Arbitrary Constants } \\
(\mu) \times \mathbf{1 0}^{-\mathbf{4}} \mathbf{P} \text {. aeruginosa }\end{array}$ & $\begin{array}{c}\text { Slope of Arbitrary Constants } \\
(\boldsymbol{\mu}) \times \mathbf{1 0}^{-\mathbf{4}} \text { S. aureus }\end{array}$ \\
\hline ChNPs & $-(5.33 \pm 0.86)$ & $-(5.02 \pm 0.56)$ \\
ChNPs $+\mathrm{PEF}$ & $-(10.3 \pm 0.96)$ & $-(8.03 \pm 0.75)$ \\
\hline
\end{tabular}

Furthermore, the cytotoxicity towards the bacterial strains was obtained by measuring the levels of $\mathrm{LDH}$, protein leakage and nucleic acid. The quantitative evaluation of LDH and protein leakage percentages relative to the negative control samples is considered as an effective biomarker for bacterial cell membrane damage. The loss of cell membrane integrity as a result of treatment has been manifested by its leakage from the inside of bacteria into the extracellular medium [59]. Both Figures 9 and 10 show the relative change in percentages of protein leakage and LDH values for P. aeruginosa and S. aureus samples treated by ChNPs and PEF each alone and combined with exposure to PEF. 


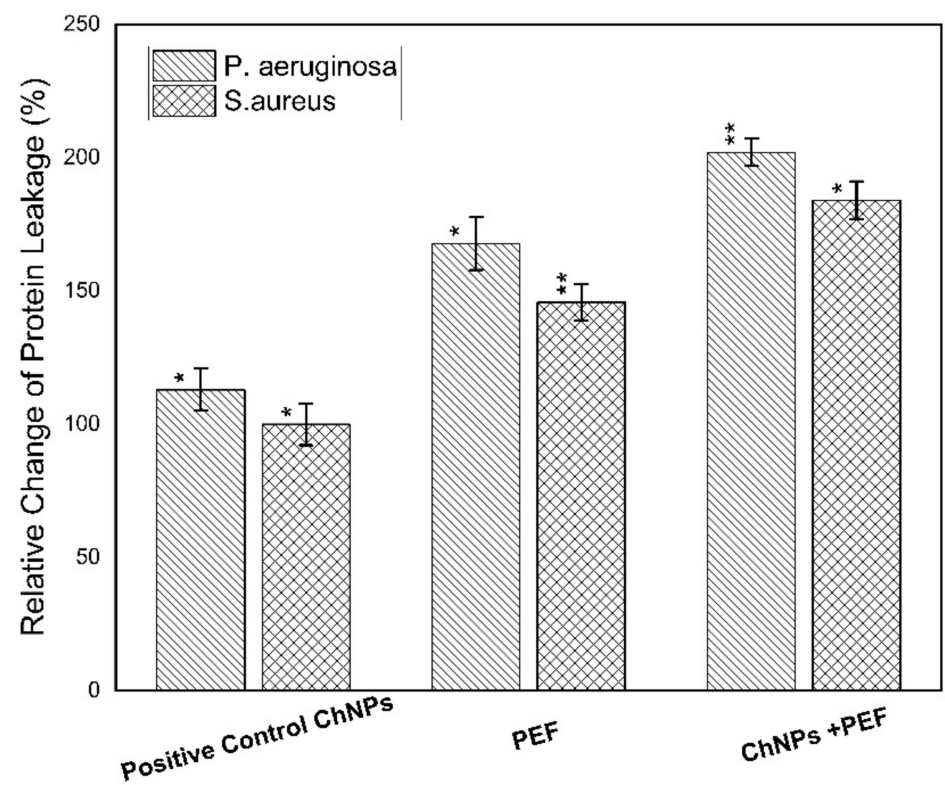

Figure 9. Relative change of protein leakage percentage for P. aeruginosa and S. aureus samples treated by ChNPs and PEF each alone and combined with exposure to PEF. * statistically significant, ** statistically highly significant.

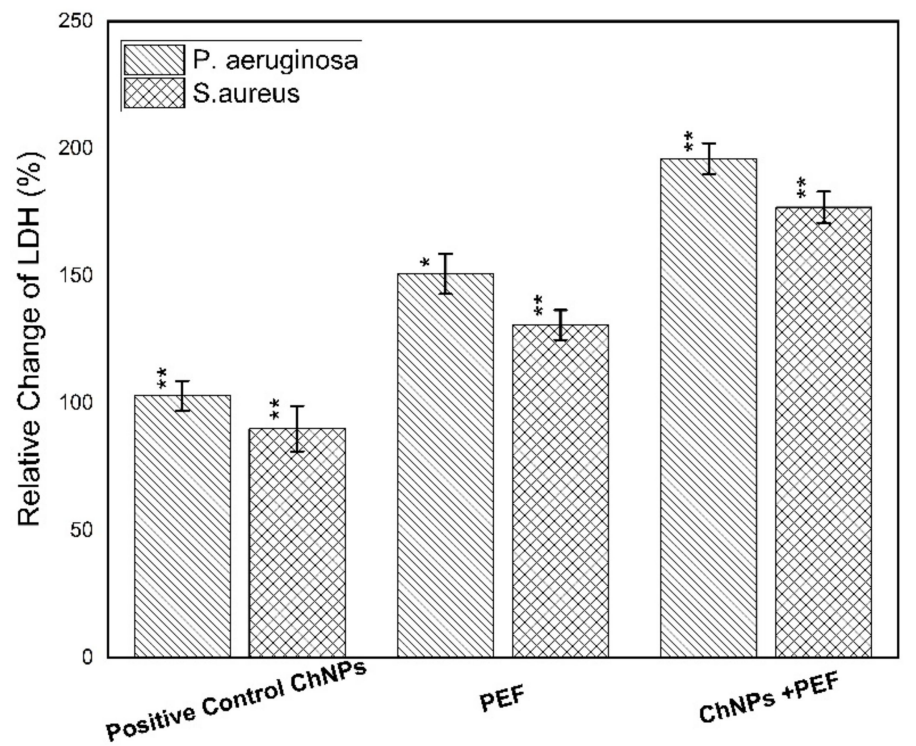

Figure 10. Relative change of LDH percentage for P. aeruginosa and S. aureus samples treated by ChNPs and PEF each alone and combined with exposure to PEF. * statistically significant, ${ }^{* *}$ statistically highly significant.

Of note, the leakage of intercellular macromolecules such as proteins outside the cell demonstrates the increase in membrane permeability. Our findings validate the highest effect of treatment by both ChNPs and PEF than for each one alone for P. aeruginosa and S. aureus on the order of $(180 \mu \mathrm{g} / \mathrm{mg}-\mathrm{ChNPs}+\mathrm{PEF})>(168 \mu \mathrm{g} / \mathrm{mg}-\mathrm{PEF})>(157 \mu \mathrm{g} / \mathrm{mg}-$ ChNPs $)$ and $(160 \mu \mathrm{g} / \mathrm{mg}-\mathrm{ChNPs}+\mathrm{PEF})>(146 \mu \mathrm{g} / \mathrm{mg}-\mathrm{PEF})>(129 \mu \mathrm{g} / \mathrm{mg}-\mathrm{ChNPs})$, respectively. Moreover, the release of LDH enzyme into the surrounding extracellular space only happens when cell membrane integrity is compromised. When LDH is present in the cell culture, it reduces $\mathrm{NAD}^{+}$to $\mathrm{NADH}$ and $\mathrm{H}^{+}$through the oxidation of lactate to pyruvate. Afterward, the catalyst (diaphorase) then transfers $\mathrm{H} / \mathrm{H}^{+}$from $\mathrm{NADH}+\mathrm{H}^{+}$to the tetrazolium salt INT to form the red-colored formazan salt. Based on this standard, the colorimetric absorbance is proportional to the amount of damaged cells in the culture. The 
LDH levels were normalized to the negative control samples, averaged and represented as percentages. The P. aeruginosa data indicated elevations by 1 -fold $(380 \mu \mathrm{U} / \mathrm{mL}-\mathrm{ChNPs}), 1.5-$ fold $(475 \mu \mathrm{U} / \mathrm{mL}-\mathrm{PEF})$ and 2 -fold $(570 \mu \mathrm{U} / \mathrm{mL}$-ChNPs $+\mathrm{PEF})$ compared to control values as shown in Figure 10. Similarly, the S. aureus data showed an increase of LDH levels by < 1-fold (170 $\mu \mathrm{U} / \mathrm{mL}$-ChNPs), 1-fold ( $425 \mu \mathrm{U} / \mathrm{mL}$-PEF) and 1.5 -fold ( $570 \mu \mathrm{U} / \mathrm{mL}$-ChNPs + PEF) compared to control ones as shown in Figure 10. Due to the inherent linearity of this LDH cytotoxicity assay, it may be presumed that the percentage of cellular damage of samples treated by ChNPs and PEF represents the highest injury level. Collectively, our results show that the treatment with ChNPs in combination with PEF remarkably disrupted the bacterial membranes, consequently leading to intracellular leakage of macromolecules. The exposure to PEF has the ability to cause outer charges to be disordered and so, the binding of even small amounts of ChNPs to the cellular outer surface has an additional bacteriostatic action compared to using ChNPs alone. Not only this, but it also has a bactericidal effect resulting from the ability of more ChNPs to enter the cell and combine directly into DNA and hinder its replication ability. Nucleic acids have a UV absorption maximum at a wavelength of $260 \mathrm{~nm}$, and the concentration of nucleic acid was directly proportional to the OD value. The absorbance values might in part be due to the release of nucleic acid-related molecules, such as nucleotides, or even to proteins [60] so it is supposed that there is a direct relationship between bacterial nucleic acid leakage and bacterial inactivation. The OD values confirmed the highest effect of treatment by ChNPs combined with PEF as shown in Figure 11. The synergistic combination effect is depicted in the order of $\mathrm{OD}_{260}$ as follow; $(0.98-\mathrm{ChNPs}+\mathrm{PEF})>(0.78-\mathrm{PEF})>(0.49-\mathrm{ChNPs})$ and $(0.91-\mathrm{ChNPs}+\mathrm{PEF})>(0.73-\mathrm{PEF})>(0.58-\mathrm{ChNPs})$ for $P$. aeruginosa and S. aureus, respectively.

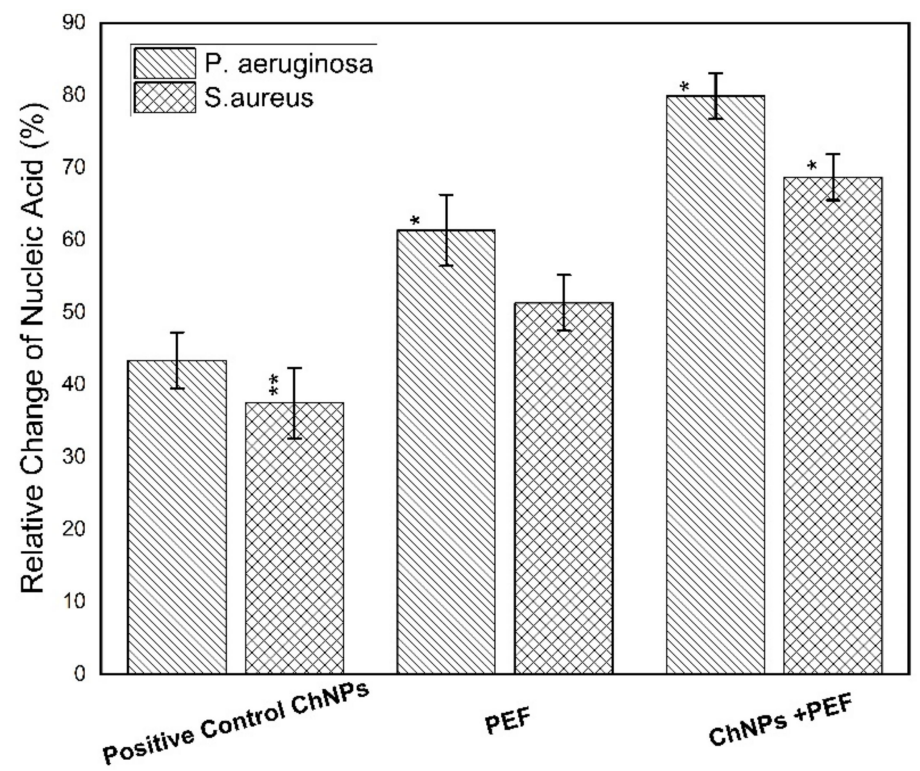

Figure 11. Relative change of nucleic acid percentage for P. aeruginosa and S. aureus samples treated by ChNPs and PEF each alone and combined with exposure to PEF. * statistically significant, ** statistically highly significant.

The use of PEF may have a specific cellular response against DNA synthesis, transcription, and protein synthesis [61-64], so our suggestion is to take advantage of using $\mathrm{PEF}$ as a wound healing accelerator and its synergistic effect as an antibacterial enhancer. PEF has a direct impact on the wound healing process by altering or augmenting preexisting endogenous electrical fields. It may also have multiple mechanisms of action that help in angiogenesis and increase collagen synthesis in addition to its bactericidal effect $[64,65]$. From this standpoint, the importance of our new combination lies in the use of safe nanomaterials such as chitosan with unique characteristics and exposure to PEF of low frequencies with non-thermal and non-harmful effects. Summing up, all the previous 
possible antimicrobial mechanisms of ChNPs and PEF are represented in schematic diagram to show how it may work effectively against $P$. aeruginosa and $S$. aureus are shown in Figure 12.

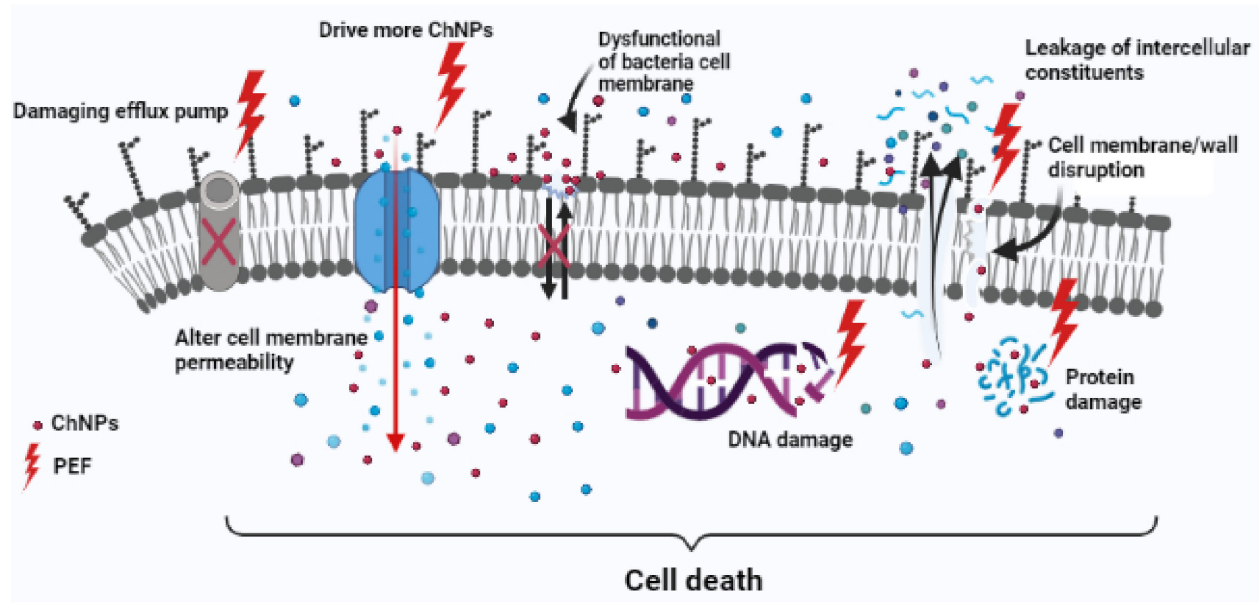

Figure 12. Schematic diagram of possible antimicrobial synergism of ChNPs and PEF against bacterial cell.

\section{Conclusions}

Our data confirms the synergistic antibacterial effect of ChNPs and exposure to PEF against $P$. aeruginosa and $S$. aureus. Specifically, the antibacterial impact of exposure to ChNPs and PEF is found to be higher against P. aeruginosa than $S$. aureus bacteria. Such a new combination with PEF has a positive impact not only by accelerating the wound healing process but also by acting as an antibacterial cofactor with ChNPs. These results are promising and could be extended in the future to examine several other types of bacteria and the application in vivo along with all treatment conditions should be studied.

Author Contributions: Conceptualization, M.I.E.-K. and M.A.; methodology, M.I.E.-K.; formal analysis, M.I.E.-K.; investigation, M.I.E.-K.; writing-original draft preparation, M.I.E.-K. and M.A.; writing-review and editing, M.I.E.-K., M.A. and N.S. All authors have read and agreed to the published version of the manuscript.

Funding: This research received no external funding.

Conflicts of Interest: The authors declare no conflict of interest.

\section{References}

1. Kiroshka, V.V.; Petrova, V.A.; Chernyakov, D.D.; Bozhkova, Y.O.; Kiroshka, K.V.; Baklagina, Y.G.; Romanov, D.P.; Kremnev, R.V.; Skorik, Y.A. Influence of chitosan-chitin nanofiber composites on cytoskeleton structure and the proliferation of rat bone marrow stromal cells. J. Mater. Sci. Mater. Med. 2017, 28, 21. [CrossRef]

2. Petrova, V.A.; Elokhovskiy, V.Y.; Raik, S.V.; Poshina, D.N.; Romanov, D.P.; Skorik, Y.A. Alginate gel reinforcement with chitin nanowhiskers modulates rheological properties and drug release profile. Biomolecules 2019, 9, 291. [CrossRef]

3. Sarin, S.; Kolesnikova, S.; Postnova, I.; Ha, C.S.; Shchipunov, Y. Bionanocomposite from self-assembled building blocks of nacre-like crystalline polymorph of chitosan with clay nanoplatelets. RSC Adv. 2016, 6, 33501-33509. [CrossRef]

4. Sun, F.; Pang, X.; Zhitomirsky, I. Electrophoretic deposition of composite hydroxyapatite-chitosan-heparin coatings. J. Mater. Process. Technol. 2009, 209, 1597-1606. [CrossRef]

5. Kong, M.; Chen, X.G.; Xing, K.; Park, H.J. Antimicrobial properties of chitosan and mode of action: A state of the art review. Int. J. Food Microbiol. 2010, 144, 51-63. [CrossRef]

6. Chandrasekaran, M.; Kim, K.D.; Chun, S.C. Antibacterial Activity of Chitosan Nanoparticles: A Review. Processes 2020, 8, 1173. [CrossRef]

7. Raafat, D.; Von Bargen, K.; Haas, A.; Sahl, H.-G. Insights into the mode of action of chitosan as an antibacterial compound. Appl. Environ. Microbiol. 2008, 74, 3764-3773. [CrossRef] [PubMed] 
8. Ryan, C.; Alcock, E.; Buttimer, F.; Schmidt, M.; Clarke, D.; Pemble, M.; Bardosova, M. Synthesis and characterisation of crosslinked chitosan composites functionalised with silver and gold nanoparticles for antimicrobial applications. Sci. Technol. Adv. Mater. 2017, 18, 528-540. [CrossRef] [PubMed]

9. Susilowati, E. Green synthesis of silver-chitosan nanocomposite and their application as antibacterial material. J. Phys. Conf. Ser. 2019, 1153, 012135. [CrossRef]

10. Małgorzata, Z.; Anna, D.; Yury, A.; Valentina, A.; Adam, C.; Iwona, K. Silver Nanoparticles on Chitosan/Silica Nanofibers: Characterization and Antibacterial Activity. Int. J. Mol. Sci. 2020, 21, 166.

11. Yadav, A.V.; Bhise, B. Chitosan: A potencial biomaterial effective against typhoid. Curr. Sci. 2004, 87, 1176-1178.

12. Zazouli, M.A.; Yousefi, M.; Kor, Y.; Roohafzaee, M. Inactivation of Escherichia coli in Water by Combined Process of Silver Nanoparticle and Ultraviolet Radiation. Health Scope 2016. [CrossRef]

13. Fojt, L.; Strasak, L.; Vetterl, V.; Smarda, J. Comparison of the low-frequency magnetic field effects on bacteria Escherichia coli, Leclercia adecarboxylata and Staphylococcus aureus. Bioelectrochemistry 2004, 63, 337-341. [CrossRef]

14. Inhan-Garip, A.; Aksu, B.; Akan, Z.; Akakin, D.; Ozaydin, A.N.; San, T. Effect of extremely low frequency electromagnetic fields on growth rate and morphology of bacteria. Int. J. Radiat. Biol. 2011, 87, 1155-1161. [CrossRef] [PubMed]

15. Cellini, L.; Grande, R.; Di Campli, E.; Di Bartolomeo, S.; Di Giulio, M.; Robuffo, I.; Trubiani, O.; Mariggiò, M.A. Bacterial response to the exposure of $50 \mathrm{~Hz}$ electromagnetic fields. Bioelectromagnetics 2008, 29, 302-311. [CrossRef]

16. Belyaev, I. Toxicity and SOS-response to ELF magnetic fields and nalidixic acid in E. coli cells. Mutat. Res. 2011, 722, 56-61. [CrossRef]

17. Segatore, B.; Setacci, D.; Bennato, F.; Cardigno, R.; Amicosante, G.; Iorio, R. Evaluations of the Effects of Extremely Low-Frequency Electromagnetic Fields on Growth and Antibiotic Susceptibility of Escherichia coli and Pseudomonas aeruginosa. Int. J. Microbiol. 2012, 2012, 1-7. [CrossRef]

18. El-Kaliuoby, M.I.; El-Khatib, A.M.; Khalil, A.M. Does Engineering of Nano Shapes Have Antibacterial Synergy with Magnetic Signals Exposure? Surf. Innov. 2019, 7, 260-269. [CrossRef]

19. El-Khatib, A.M.; Khalil, A.M.; El-Kaliuoby, M.I.; El-Khatib, M. The Combined Effects of Multi-Sized Silver Nanoparticles by Arc Discharge and Pulsed Magnetic Fields Exposure on K. pneumoniae. Bioinspir. Biomim. Nanobiomater. 2019, 8, 154-160. [CrossRef]

20. El-kaliuoby, M.I.; Khalil, A.M.; El-Khatib, A.M.; Shalaby, T.I. Synergistic antibacterial effect of silver nanoparticles and extremely low frequency pulsed magnetic fields on Klebsiella pneumoniae. J. Appl. Biol. Biotech. 2018, 6, 039-045.

21. El-Kaliuoby, M.I.; Khalil, A.M.; El-Khatib, A.M.; Shehata, N. Antibacterial Synergism of Electrospun Nanofiber Mats Functioned with Silver Nanoparticles and Pulsed Electromagnetic Waves. Polymers 2021, 13, 277. [CrossRef] [PubMed]

22. El-kaliuoby, M.I.; Hamouda, R.; El-Khatib, A.M. Novel approach to enhancing remineralization of tooth surface by magnetic field exposure. Surf. Innov. 2020, 9, 49-56. [CrossRef]

23. Seeliger, C.; Falldorf, K.; Sachtleben, J.; Griensven, M. Low-frequency pulsed electromagnetic fields significantly improve time of closure and proliferation of human tendon fibroblasts. Eur. J. Med. Res. 2014, 19, 37. [CrossRef] [PubMed]

24. Pirogova, E.; Vojisavljevic, V.; Ahmed, I. Investigation of the effect of Extremely Low Frequency (ELF) Pulsed Electromagnetic Field (PEMF) on Collagenase Enzyme Kinetics. In Proceedings of the 6th International Joint Conference on Biomedical Engineering Systems and Technologies INSTICC, Barcelona, Spain, 11-14 February 2013; BIODEVICES 2013: Lisbon, Portugal, 2013; pp. 143-147.

25. Jamil, M.M.A.; Zaltum, M.A.; Youseffi, M.; Javid, F. Study on Pulse Electric Field Exposure Effect on HeLa Cells For Wound Healing Application. International Conference on Biomedical Engineering (ICoBE). J. Phys. Conf. Ser. 2019, 1372, 012021. [CrossRef]

26. Rivera Aguayo, P.; Bruna Larenas, T.; Alarcón Godoy, C.; Cayupe Rivas, B.; González-Casanova, J.; Rojas-Gómez, D.; Caro Fuentes, N. Antimicrobial and Antibiofilm Capacity of Chitosan Nanoparticles against Wild Type Strain of Pseudomonas sp. Isolated from Milk of Cows Diagnosed with Bovine Mastitis. Antibiotics 2020, 9, 551. [CrossRef] [PubMed]

27. Golberg, A.; Broelsch, G.F.; Bohr, S.; Mihm, M.C.; Austen, W.G.; Albadawi, H.; Yarmush, M.L. Non-thermal, pulsed electric field cell ablation: A novel tool for regenerative medicine and scarless skin regeneration. Technology 2013, 01, 1-7. [CrossRef] [PubMed]

28. Golberg, A.; Khan, S.; Belov, V.; Quinn, K.P.; Albadawi, H.; Felix Broelsch, G.; Yarmush, M.L. Skin Rejuvenation with Non-Invasive Pulsed Electric Fields. Sci. Rep. 2015, 5, 10187. [CrossRef]

29. Amin, A.N.; Cerceo, E.A.; Deitelzweig, S.B.; Pile, J.C.; Rosenberg, D.J.; Sherman, B.M. Hospitalist perspective on the treatment of skin and soft tissue infections. Mayo Clin. Proc. 2014, 89, 1436-1451. [CrossRef] [PubMed]

30. Bjarnsholt, T.; Kirketerp-Møller, K.; Jensen, P.Ø.; Madsen, K.G.; Phipps, R.; Krogfelt, K.; Høiby, N.; Givskov, M. Why chronic wounds will not heal: A novel hypothesis. Wound Rep. Regen. 2008, 16, 2-10. [CrossRef]

31. Schaber, J.A.; Triffo, W.J.; Suh, S.J.; Oliver, J.W.; Hastert, M.C.; Griswold, J.A.; Auer, M.; Hamood, A.N.; Rumbaugh, K.P. Pseudomonas aeruginosa Forms Biofilms in Acute Infection Independent of Cell-to-Cell Signaling. Infect. Immun. 2007, 75, 3715-3721. [CrossRef] [PubMed]

32. Church, D.; Elsayed, S.; Reid, O.; Winston, B.; Lindsay, R. Burn Wound Infections. Clin. Microbiol. Rev. 2006, 19, 403-434. [CrossRef]

33. Hempel, K.; Pané-Farré, J.; Otto, A.; Sievers, S.; Hecker, M.; Becher, D. Quantitative Cell Surface Proteome Profiling for SigBDependent Protein Expression in the Human Pathogen Staphylococcus aureusvia Biotinylation Approach. J. Proteome Res. 2010, 9, 1579-1590. [CrossRef] 
34. Abeyrathne, C.D.; Huynh, D.H.; Mcintire, T.W.; Nguyen, T.C.; Nasr, B.; Zantomio, D.; Chana, G.; Abbott, I.; Choong, P.; Catton, M.; et al. Lab on a chip sensor for rapid detection and antibiotic resistance determination of Staphylococcus aureus. Analyst 2016, 141, 1922-1929. [CrossRef] [PubMed]

35. Elmi, F.; Alinezhad, H.; Moulana, Z.; Salehian, F.; Mohseni Tavakkoli, S.; Asgharpour, F.; Fallah, H.; Elmi, M.M. The use of antibacterial activity of $\mathrm{ZnO}$ nanoparticles in the treatment of municipal wastewater. Water Sci. Technol. 2014, 70, 763-770. [CrossRef] [PubMed]

36. Fadel, M.; Ali, A.M.; Elkhatib, W.M.; Aboutalib, A.M.; Abdelbacki Khalil, A.M.; Serag, N. Control of the Activity of Pseudomonas Aeruginosa by Positive Electric Impulses at Resonance Frequency. J. Am. Sci. 2013, 9, 120-130.

37. El-kaliuoby, M.I.; Khalil, A.M.; El-Khatib, A.M. Alterations of Bacterial Dielectric Characteristics Due to Pulsed Magnetic Field Exposures. Bioinspir. Biomim. Nanobiomater. 2020, 9, 103-111. [CrossRef]

38. Dhermendra, K.; Behari, T.J.; Sen, P. Time and dose-dependent antimicrobial potential of Ag nanoparticles synthesized by top-down approach. Curr. Sci. 2008, 95, 647-655.

39. Kim, S.H.; Lee, H.S.; Ryu, D.S.; Choi, S.J.; Lee, D.S. Antibacterial Activity of Silver-nanoparticles Against Staphylococcus aureus and Escherichia coli. Korean J. Microbiol. Biotechnol. 2011, 39, 77-85.

40. Bradford, M.M. A rapid and sensitive for the quantitation of microgram quantities of protein utilizing the principle of protein-dye binding. Anal. Biochem. 1967, 72, 248-254. [CrossRef]

41. Li, W.R.; Xie, X.B.; Shi, Q.S.; Zeng, H.Y.; Ou-Yang, Y.S.; Chen, Y.B. Antibacterial activity and mechanism of silver nanoparticles on Escherichia coli. Appl. Microbiol. Biotechnol. 2010, 85, 1115-1122. [CrossRef]

42. Reddy, L.S.; Nisha, M.M.; Joice, M.; Shilpa, P.N. Antimicrobial activity of zinc oxide (ZnO) nanoparticle against Klebsiella pneumoniae. Pharm. Biol. 2014, 52, 1388-1397. [CrossRef]

43. Jia, Z.; Shen, D.; Xu, W. Synthesis and antibacterial activities of quaternary ammonium salt of chitosan. Carbohydr. Res. 2001, 333, 1-6. [CrossRef]

44. Yi, Y.; Wang, Y.; Liu, H. Preparation of new crosslinked chitosan with crown ether and their adsorption for silver ion for antibacterial activities. Carbohydr. Polym. 2003, 53, 425-430. [CrossRef]

45. Qi, L.; Xu, Z.; Jiang, X.; Hu, C.; Zou, X. Preparation and antibacterial activity of chitosan nanoparticles. Carbohydr. Res. 2004, 339, 2693-2700. [CrossRef] [PubMed]

46. Birsoy, K.; Wang, T.C.; Chen, W.W.; Freinkman, E.; Abu-Remaileh, M.; Sabatini, D.M. An essential role of the mitochondrial electron transport chain in cell proliferation is to enable aspartate synthesis. Cell 2015, 162, 540-551. [CrossRef] [PubMed]

47. Du, W.-L.; Niu, S.-S.; Xu, Y.-L.; Xu, Z.-R.; Fan, C.-L. Antibacterial activity of chitosan tripolyphosphate nanoparticles loaded with various metal ions. Carbohydr. Polym. 2009, 75, 385-389. [CrossRef]

48. Joshi, M.; Ali, S.W.; Purwar, R. Ecofriendly antimicrobial finishing of textile using bioactive agents based on natural products. Indian J. Fibre Text. Res. 2009, 30, 295-304.

49. Wang, X.; Du, Y.; Liu, H. Preparation, characterization and antimicrobial activity of chitosan-Zn complex. Carbohydr. Polym. 2004, 56, 21-26. [CrossRef]

50. Chung, Y.-C.; Su, Y.-P.; Chen, C.-C.; Jia, G.; Wang, H.-L.; Wu, J.C.G.; Lin, J.-G. Relationship between antibacterial activity of chitosan and surface characteristics of cell wall. Acta Pharmacol. Sin. 2004, 25, 932-936. [PubMed]

51. No, H.K.; Park, N.Y.; Lee, S.H.; Meyers, S.P. Antibacterial activity of chitosans and chitosan oligomers with different molecular weights. Int. J. Food Microbiol. 2002, 74, 65-72. [CrossRef]

52. Divya, K.; Vijayan, S.; George, T.K.; Jisha, M.S. Antimicrobial properties of chitosan nanoparticles: Mode of action and factors affecting activity. Fibers Polym. 2017, 18, 221-230. [CrossRef]

53. Badawy, M.E.I.; Lotfy, T.M.R.; Shawir, S.M.S. Preparation and antibacterial activity of chitosan-silver nanoparticles for application in preservation of minced meat. Bull. Natl. Res. Centre 2019, 43, 83. [CrossRef]

54. Tran, H.V.; Tran, L.D.; Ba, C.T.; Vu, H.D.; Nguyen, T.N.; Pham, D.G.; Nguyen, P.X. Synthesis, characterization, antibacterial and antiproliferative activities of monodisperse chitosan-based silver nanoparticles. Colloids Surfaces A Physicochem. Eng. Asp. 2010, 360, 32-40. [CrossRef]

55. Zhou, Q.; Zhang, J.; Saba, T.; Yue, Z.; Li, W.; Anderson, J.A.; Wang, X. Electric-Field-Assisted Facile Synthesis of Metal Nanoparticles. ACS Sustain. Chem. Eng. 2018, 7, 1271-1278. [CrossRef]

56. Luo, W.; Han, Z.; Zeng, X.; Yu, S.; Kennedy, J.F. Study on the degradation of chitosan by pulsed electric fields treatment. Innov. Food Sci. Emerg. Technol. 2010, 11, 587-591. [CrossRef]

57. Dan, G.; Zhang, Z.H.; Zeng, X.A.; Han, Z.; Luo, W.B.; Tang, C.; Quek, S.Y. Synergetic Effects of Pulsed Electric Field and Ozone Treatments on the Degradation of High Molecular Weight Chitosan. Int. J. Food Eng. 2014, 10, 775-784. [CrossRef]

58. Shang, L.; Nienhaus, K.; Nienhaus, G. Engineered nanoparticles interacting with cells: Size matters. J. Nanobiotechnol. 2014, 12, 5. [CrossRef] [PubMed]

59. Oh, S.-J.; Kim, H.; Liu, Y.; Han, H.-K.; Kwon, K.; Chang, K.-H.; Park, K.; Kim, Y.; Shim, K.; An, S.S.A.; et al. Incompatibility of silver nanoparticles with lactate dehydrogenase leakage assay for cellular viability test is attributed to protein binding and reactive oxygen species generation. Toxicol. Lett. 2014, 225, 422-432. [CrossRef]

60. Yao, C.; Li, X.; Bi, W.; Jiang, C. Relationship between membrane damage, leakage of intracellular compounds, and inactivation of Escherichia coli treated by pressurized $\mathrm{CO}_{2}$. J. Basic Microbiol. 2013, 54, 858-865. [CrossRef] 
61. Guerriero, F.; Botarelli, E.; Mele, G.; Polo, L.; Zoncu, D.; Renati, P.; Sgarlata, C.; Rollone, M.; Ricevuti, G.; Maurizi, N.; et al Effectiveness of an Innovative Pulsed Electromagnetic Fields Stimulation in Healing of Untreatable Skin Ulcers in the Frail Elderly: Two Case Reports. Case Rep. Dermatol. Med. 2015. [CrossRef]

62. Ali, F.M.; Elkhatib, A.M.; Aboutaleb, W.M.; Abdelbacki, A.M.; Khalil, A.M.; El-kaliuoby, M.I. Control the Activity of Ralstonia Solanacearum Bacteria by Using Pulsed Electric Field. Jokull J. 2014, 64, 256-269.

63. Balabel, N.M.; El-Kaliuoby, M.I.; Khalil, A.M. Effect of square pulsed magnetic field exposure on growth kinetics of Dickeya solani. Arch. Phytopathol. Plant Prot. 2019. [CrossRef]

64. Goudarzi, I.; Hajizadeh, S.; Salmani, M.E.; Abrari, K. Pulsed electromagnetic fields accelerate wound healing in the skin of diabetic rats. Bioelectromagnetics 2010, 31, 318-323. [CrossRef] [PubMed]

65. Ali, Y.; Jalilifar, M. Electromagnetic Fields in the Treatment of Wound: A Review of Current Techniques and Future Perspective. J. Pure Appl. Microbiol. 2014, 8, 2863-2877. 